\title{
IDENTIFIKASI ETIOLOGI DIARE AKUT PADA ANAK DENGAN TEKNOLOGI GABUNGAN REAKSI RANTAI POLIMERASE DAN SPEKTROMETRI MASSA DI RUMAH SAKIT PENYAKIT INFEKSI PROF. DR. SULIANTI SAROSO
}

\author{
Tony Soetanto ${ }^{1}$, Ina Susianti Tima ${ }^{2}$ \\ ${ }^{1}$ RSPI Prof Dr Sulianti Saroso, ${ }^{2}$ Departemen Patologi Klinik FKUI/RSCM
}

\begin{abstract}
Abstrak :PCR-electrospray ionization mass spectrometry (PCR-ESI/MS), suatu peralatan baru yang mampu mendeteksi hampir semua mikroorganisme patogen, namun belum pernah digunakan di Indonesia. Tujuan penelitian ini untuk memperoleh pengalaman dengan PCR/ESI-MS dan panel food borne pathogen, mengetahui kelebihan dan kelemahan teknologi ini. Rancangan penelitian potong lintang, menggunakan spesimen dari poliklinik anak, dilakukan dari bulan juli 2012 hingga desember 2012, dan akhirnya 24 spesimen diperiksa dengan PCR/ESI-MS. Karakteristik diare terdiri dari 12 dengan lendir, 3 diare berdarah dan 20 hanya diare cair saja. Pada sebagian besar kasus dijumpai lebih dari satu bakteri. Bakteri E. coli FDA29 ditemukan pada kasus disertai demam dan sakit perut, namun tidak ada pada kasus tanpa kelainan tersebut. Jenis bakteri dengan PCR/ESI-MS berbeda dengan kultur. Metoda ini dapat mendeteksi bakteri dalam waktu 24 jam dan sangat bermanfaat pada wabah. Berdasarkan kemampuan metoda ini untuk mendeteksi beberapa bakteri dari satu spesimen, tampaknya biayanya tidak lebih mahal dibanding kultur. Metoda ini sangat bermanfaat untuk surveilans dalam hal menemukan kesamaaan antara penyebab penyakit dan pejamu.
\end{abstract}

Kata kunci : Diare, PCR-ESI/MS

\section{ETIOLOGY IDENTIFICATION OF ACCUTE DIARRHEA IN CHILDREN USING THE COMBINED POL YMERASE CHAIN REACTION AND MASS SPECTROMETRY IN INFECTIOUS DISEASE HOSPITAL PROF DR SULIANTI SAROSO}

\begin{abstract}
PCR-electrospray ionization mass spectrometry (PCR-ESI/MS), a new equipment that can detect almost all human patogenic microorganism, but never used before in Indonesia. The aim of this study to get experience with PCR/ESI-MS and panel food borne pathogen, to know the profile of bacteria that caused diarhea by PCR/ESI-MS, and know the advantage and handicapped of this equipment.Study design was descriptive cross sectional, using specimen from Child ambulatory clinic, was done from July 2012 until December 2012 and finally 24 was examined with PCR/ESI-MS. Clinical characteristic consist of fever 9 (37,5\%), vomiting 17 (70.8\%)and abdominal pain 11 (45.8\%). Mayority (75\%) got diarhea from 3-5 daily. Characteristic of diarhea, 12 cases with mucus, 3 cases bloody diarhea and 20 cases only liquid faeces. In most cases, we found multiple bacteria. Bacteria E. coli FDA29 was detected on cases with fever and abdominal pain but not found in cases without those manifestation. Type of bacteria in this study was different with cultur result. This method can detect bacteria in 24 hours, and very useful in outbreak, and if we calculate the cost and the ability of this metod to detect several bacteria from single specimen, it seems nearly the same. It seems that this method will be very useful for surveilans ie to find similarity between agent and host.

Keywords: diarrhea, PCR/ESI-MS
\end{abstract}

Korespondensi :

Dr. Tony Soetanto, SpPK

RSPI Prof. Dr. Sulianti Saroso Jakarta,Jl.Baru

Sunter Permai Raya Jakarta Utara 14340

Phone : 021-6506559 Fax: 021-6401411

Email:tonyrspiss@gmail.com

\section{PENDAHULUAN}

Diare didefinisikan sebagai buang air besar cair atau lembek dengan frekuensi lebih dari 3 kali sehari, dengan atau tanpa darah dan atau lendir dalam tinja ${ }^{1}$.
Penyakit diare merupakan penyebab kematian nomor dua pada anak usia balita, dan tiap tahunnya, 760000 anak meninggal akibat diare. Serangan diare akan mengurangi pemasukan nutrisi yang diperlukan untuk pertumbuhan anak. Penyakit diare merupakan salah satu penyebab utama malnutrisi anak, dan sebaliknya anak dengan malnutrisi lebih mudah terserang diare ${ }^{2}$.

Penyakit akibat makanan (foodborne disease) merupakan penyakit yang sering 
ditemukan dan merupakan ancaman kesehatan masyarakat di seluruh dunia, disertai morbiditas tinggi. Penyakit akibat makanan dapat mengancam jiwa, terutama pada anak anak di negara sedang berkembang, bahkan dapat mengakibatkan cacat permanen ${ }^{2}$.

Deteksi bakteri patogen di dalam makanan merupakan hal penting untuk memastikan keamanan rantai makanan. Secara tradisional digunakan metoda biakan yang didasarkan pada pemasukan spesimen ke dalam media nutrisi untuk memperbanyak kuman, sehingga dapat dilihat pertumbuhannya. Cara konvensional ini sederhana, mudah diadaptasikan dan umumnya tidak mahal. Meskipun kepekaannya bagus, pemeriksaannya memerlukan banyak tenaga terlatih dan hasilnya tergantung pertumbuhan mikroorganisme dalam berbagai media biakan seperti media enrichment, selektif dan identifikasi. Kelemahannya, proses ini memerlukan waktu beberapa hari.,

PCR-electrospray ionization mass spectrometry (PCR-ESI/MS), merupakan pendekatan baru dengan kemampuan mendeteksihampir semua mikroorganisma patogen terhadap manusia secara langsung dari isolate mikroba maupun spesimen klinis, dan mampu mengidentifikasi secara genetika suatu kuman patogen yang belum diketahui susunan asam aminonya. Keistimewaan teknologi ini mencakup penggunaan electrospray ionization-mass spectrometry pada produk PCR yang menghasilkan gradien elektrik karena perbedaan berat molekul. Bank data disusun dari kuman yang telah diketahui sebelumnya dan seluruh genomnya telah diketahui, sehingga memungkinkan identifikasi secara lebih cepat dan mudah dibandingkan melakukan sekuensing asam deoksi ribonukleat (DNA). ${ }^{4,5}$

Rumah Sakit Penyakit Infeksi Prof. DR. Sulianti Saroso telah dilengkapi peralatan dengan teknologi Reaksi Berantai Polimerase atau Polymerase Chain Reaction (PCR) yang dikombinasikan dengan teknologi dispersi elektro ionisasi dan spektrometri massa untuk membaca keseluruhan populasi mikroorganisme yang ditemukan. Panel PCR/ESI-MS yang digunakan dalam penelitian ini meliputi panel untuk memeriksa bakteri yang sering dijumpai pada keracunan makanan, dan mampu membedakan tujuh kelompok utama subspecies Salmonella enteric : Kelompok I (Enterica), Kelompok II (Salamae),Kel ompok IIIA (Arizonae), Kelompok IIIB (Diarizonae), Kelompok IV (Houtenae), Kelompok V (Bongori), Kelompok VI (Indica) dan Kelompok VII (Unknown). Selain itu juga dapat mengidentifikasi Salmonella enterica subspeciesenterica (Kelompok I) menjadi beberapa serotype clusters, seperti Newport, enteritidis, typhimurium, typhi, paratyphi, Saintpaul, Heidelberg, dan lainnya. Panel juga dirancang untuk deteksi spesies $E$. coli dan membedakan E. coli O55: $\mathrm{H} 7$ dan O157:H7 dari E. coli lainnya, serta menemukan spesies Shigella (boydii, dysenteriae, flexneri dan sonnel) maupun spesies listeria dan membedakan Listeria monocytogenes dari spesies listeria lain. ${ }^{5}$

Mengingat peralatan ini baru pertama kali digunakan di Indonesia, dipandang perlu untuk melakukan uji coba teknologi PCR/ESI-MS dan panel food borne pathogen. Diharapkan melalui penelitian ini dapat diketahui kelebihan dan kelemahan teknologi baru tersebut, serta kemungkinan penerapannya dalam hal diagnostik maupun surveilans.

\section{METODOLOGI PENELITIAN}

Rancangan penelitian ini adalah deskriptif dengan desain penelitian potong lintang.Lokasi pengambilan spesimen di poli anak Rumah Sakit Penyakit Infeksi Prof. Dr.Sulianti Saroso. Tempat pemeriksaan spesimen di Instalasi Laboratorium Klinik Rumah Sakit Penyakit Infeksi Prof. Dr. Sulianti Saroso. Pelaksanaan penelitian dilakukan sejak juli 2012 hingga desember 2012. Subyek penelitian merupakan pasien anak dengan diare akut yang berobat jalan ke Rumah Sakit Penyakit Infeksi Prof. Dr. Sulianti Saroso. Kriteria masuk yaitu pasien rawat jalan di poli anak, kunjungan pasien merupakan kunjungan pertama, pasien anak usia $>5$ tahun, frekuensi diare $\geq 3$, lama diare $<3$ hari dan pasien / orang tua/wali setuju mengikuti penelitian 
dengan menandatangani formulir pesetujuan (informed consent). Perhitungan besar sampel yaitu pasien diare anak dan rawat jalan pada tahun 2011 sejumlah 1315 kasus dari keseluruhan pasien (46510). Sehingga prevalensi diare anak $2011=1315 / 46510$ $x 100=2,83 \%$.

Penelitian ini memakai besar sample untuk prevalensi dengan presisi 5\% sehingga didapatkan sampel sebanyak 43.

Bahan penelitian meliputi spesimen feses kasus diare. Pengambilan bahan dilakukan melalui hapusan rektal, saat penderita datang berobat. Media trasport yaitu media Carry Blair dan disimpan pada suhu $-80^{\circ} \mathrm{C}$.

Pemeriksaan menggunakan teknologi PCR/ ESI-MS dengan panel food borne pathogen diawali dengan ekstraksi asam nukleat dari spesimen, secara otomatis. Selanjutnya dilakukan proses PCR multi primer, untuk amplifikasi secara in vitro, fragmen gen tertentu yang terletak di antara pasangan oligonukleotida primer spesifik. Pada prinsipnya, teknologi PCR terdiri atas 3 tahap reaksi berbeda dalam satu siklus.Ketiga tahap tersebut meliputi denaturasi, annealing, dan polimerisasi. Pengumpulan data menggunakan seluruh data subyek penelitian dibuat dalam bentuk tabulasi untuk dianalisa secara deskriptif.

\section{HASIL PENELITIAN}

\section{Deskripsi epidemiologi diare akut pada anak dilihat dari manifestasi klinis dan karakteristik diare}

\section{a. Jumlah \& jenis kelamin subyek penelitian.}

Selama periode penelitian ini telah didapat sebanyak 43 kasus diare anak akut yang berobat ke poli anak rawat Rumah Sakit Penyakit Infeksi Prof. Dr. Sulianti Saroso di Jakarta, antara bulan juli 2012 dan bulan desember 2012. Namun hanya 24 spesimen yang selesai dianalisa dengan PCR/ESI-MS. Sembilan belas spesimen gagal diperiksa, karena peralatan PCR/ESI-MS di seluruh dunia dihentikan operasionalnya, dalam rangka penyempurnaan teknologinya, dan peralatan pengganti diperkirakan tiba di RSPI Sulianti Saroso tahun 2015. Mengingat keterbatasan waktu penelitian, diputuskan hanya 24 spesimen yang diikutkan dalam penelitian ini.

Berdasarkan jenis kelamin, subyek yang selesai diperiksa terdiri dari 10 anak laki laki dan 14 anak perempuan.

\section{b. Keluhan pasien berdasarkan anamnesis}

Karakteristik keluhan pasien yang meliputi demam, sakit perut, mual dan muntah, dapat dilihat pada diagram 1

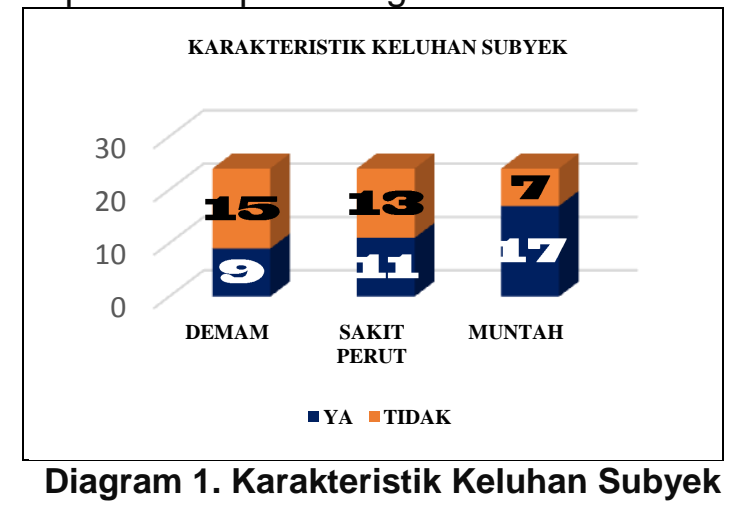

\section{c. Frekuensi diare pada subyek penelitian}

Pada diagram 2 dapat dilihat distribusi frekuensi diare pada subyek penelitian, yang terbagi dalam rentang diare per hari antara 1-5, 6-10, dan diatas 10. Berdasarkan frekuensi diare terlihat bahwa frekuensi diare mayoritas subyek kurang atau sama dengan 5 .

\section{FREKUENSI DIARE}

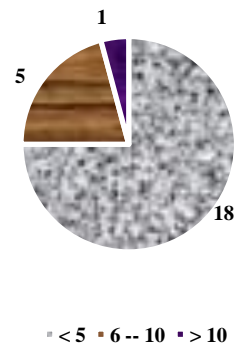

\section{Diagram 2. Frekuensi diare}

\section{d. Karakteristik diare pada subyek penelitian}

Karakteristik diare pada subyek penelitian, yang mencakup adanya lendir, darah, atau cair. Mayoritas subyek penelitian mendeskripsikan diare sebagai cair, disusul lendir, sementara darah 
hanya dikeluhkan 3 subyek. Selengkapnya dapat dilihat pada diagram 3.

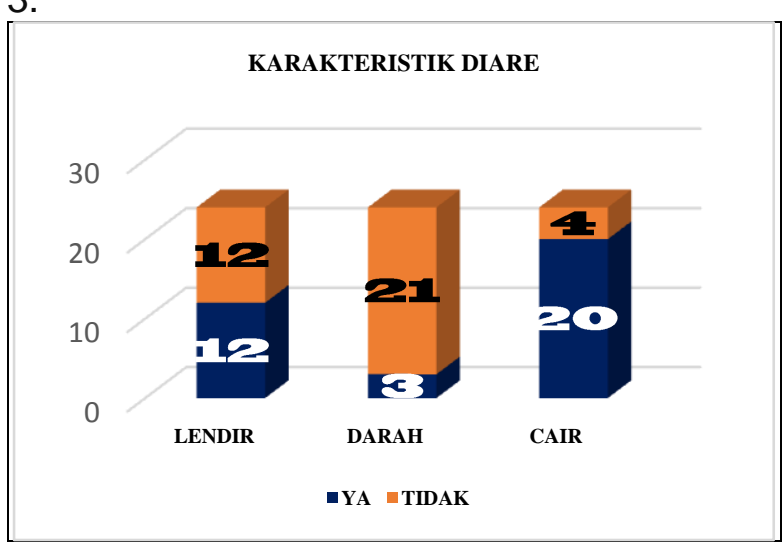

Diagram 3. Karakteristik diare

3. Pola kuman penyebab diare akut anak dengan teknologi PCR/ESI-MS

a. Jumlah Bakteri per subyek penelitian

Pada penelitian ini, ditemukan bakteri penyebab diare pada 17 spesimen, dan tidak ditemukan kuman pada 7 kasus.
Mayoritas jumlah bakteri per subyek hanya satu, namun ada yang lebih dari satu, bahkan pada satu subyek ditemukan delapan bakteri. Selengkapnya dapat dilihat pada diagram 4 .

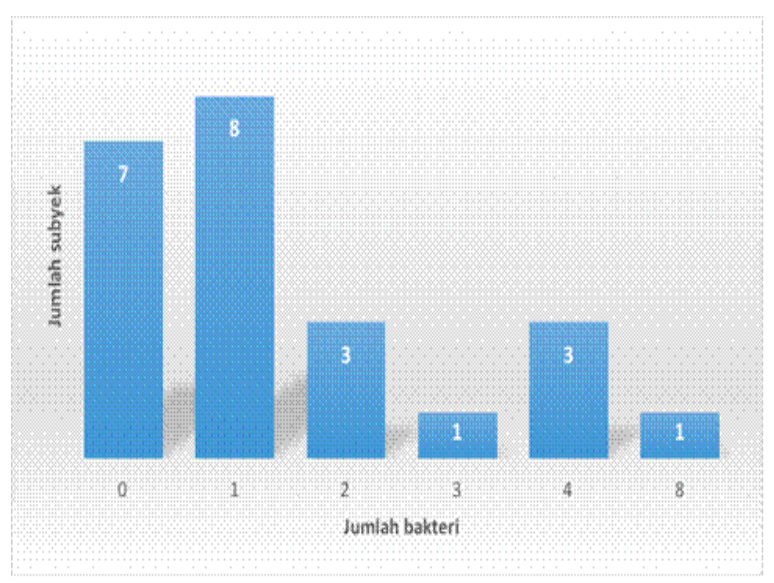

Diagram 4. Jumlah bakteri per subyek penelitian

\section{b. Jenis bakteri yang ditemukan}

Jenis bakteri yang dijumpai pada penelitian ini seluruhnya berjumlah 29 jenis bakteri, hampir semuanya $E$. coli kecuali 3 bakteri yang bukan E.coli, dan selengkapnya dapat dilihat pada tabel 1.

Tabel 1. Berbagai jenis bakteri pada penelitian ini

\begin{tabular}{|c|c|c|c|c|c|c|c|c|c|}
\hline Bakteri & $\mathbf{n}$ & Bakteri & $\mathbf{n}$ & Bakteri & $\mathbf{n}$ & Bakteri & $\mathbf{n}$ & Bakteri & $\mathrm{n}$ \\
\hline $\begin{array}{l}\text { E coli } \\
1827-9\end{array}$ & 1 & $\begin{array}{l}\text { E coli } \\
\text { Dec12a }\end{array}$ & 1 & E coli ECOR6 & 1 & $\begin{array}{l}\text { Salmonella Enterica subsp } \\
\text { Enterica serovar Havana } \\
\text { PRLSW9 }\end{array}$ & 1 & $\begin{array}{l}\text { E coli } \\
\text { ATCC8739 }\end{array}$ & 2 \\
\hline $\begin{array}{l}\text { E coli } \\
89.0609\end{array}$ & 1 & $\begin{array}{l}\text { E coli } \\
\text { DEC1a }\end{array}$ & 1 & E coli ED1a & 1 & Enterobacter cloacae & 1 & E coli IAI1 & 2 \\
\hline $\begin{array}{l}\text { E coli } \\
\text { A9619-2 }\end{array}$ & 1 & $\begin{array}{l}\text { E coli } \\
D H 10 B\end{array}$ & 1 & E coli FDA269 & 1 & Koxytoca & 1 & $\begin{array}{l}\text { E coli O } 157 \\
\text { not } H 7\end{array}$ & 2 \\
\hline $\begin{array}{l}\text { E coli } \\
B 170\end{array}$ & 1 & $\begin{array}{l}\text { E coli } \\
\text { E2348/69 }\end{array}$ & 1 & $\begin{array}{l}\text { E coli K-12 } \\
\text { substr } \\
\text { MG1655 }\end{array}$ & 1 & E coli HS & 2 & $\begin{array}{l}\text { E coli } \\
\text { SC373/2 }\end{array}$ & 2 \\
\hline $\begin{array}{l}\text { E coli } \\
\text { B2F1 }\end{array}$ & 1 & $\begin{array}{l}\text { E coli } \\
\text { ECOR28 }\end{array}$ & 1 & E coli LT-91 & 1 & E coli $277-84$ & 2 & $\begin{array}{l}\text { E coli } \\
\text { ECOR38 }\end{array}$ & 3 \\
\hline $\begin{array}{l}\text { E coli } \\
\text { Dec11a }\end{array}$ & 1 & $\begin{array}{l}\text { E coli } \\
\text { ECOR48 }\end{array}$ & 1 & E coli1758-70 & 1 & E coli 5306-56 & 2 & $T D$ & 7 \\
\hline
\end{tabular}

\section{c. Profil bakteri berdasarkan karakteristik klinis pasien.}

Profil bakteri yang ditemukan dengan teknologi PCR-ESI/MS dan dikelompokkan berdasarkan karakteristik klinis pasien. Pada tabel 2 di bawah ini, terlihat bahwa bakteri E.coli FDA 269 merupakan satu satunya bakteri yang ditemukan pada kelompok kasus demam, sakit perut, atau muntah. 
Tabel 2. Profil bakteri berdasarkan karakteristik klinis.

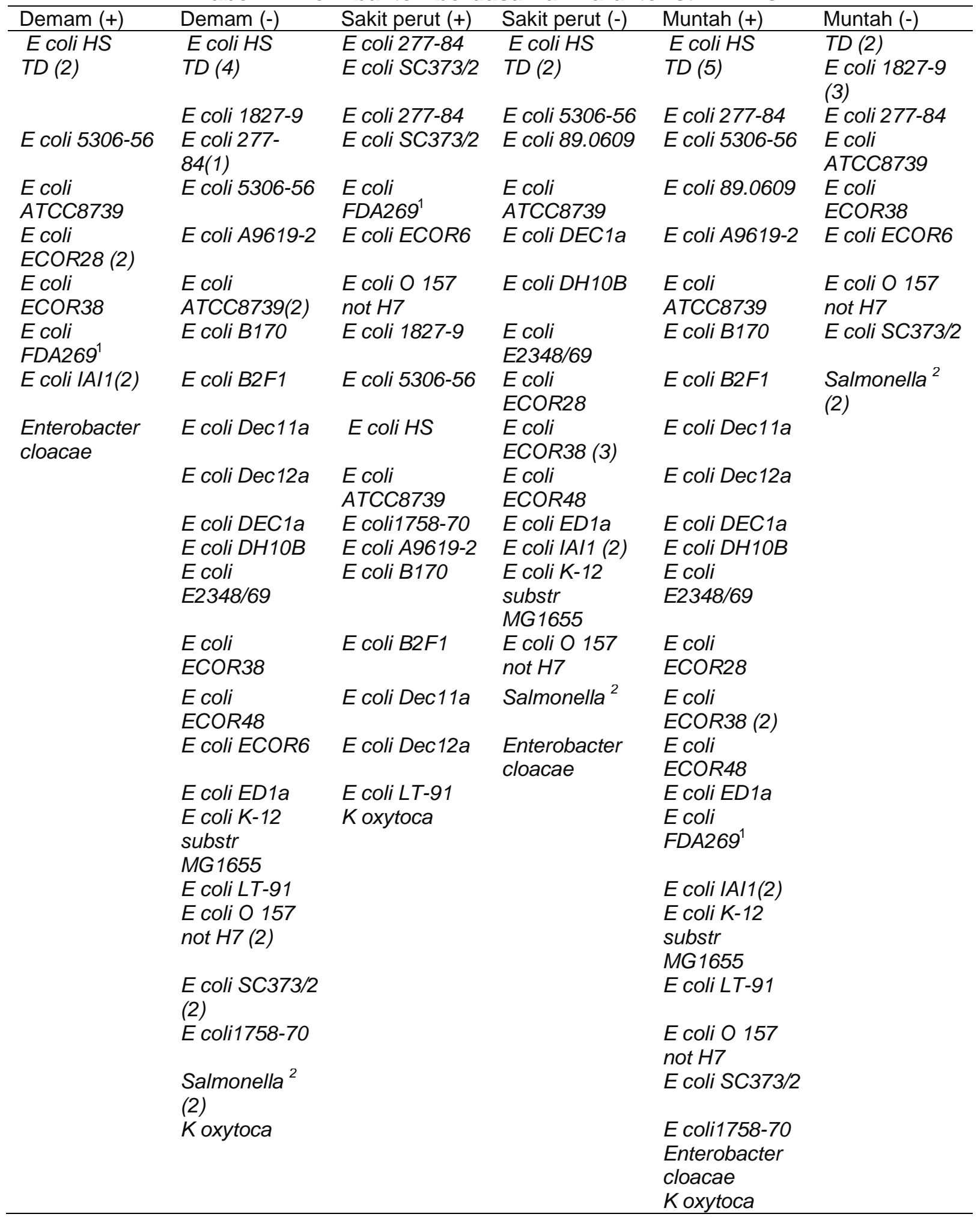

\begin{tabular}{rr}
\hline Catatan & \\
TD & : tidak ditemukan bakteri \\
1 & : Ditemukanpada demam, sakit perut dan muntah. \\
2 & : Enterica subsp Enterica serovar Havana PRLSW9
\end{tabular}




\section{d.Pola kuman berdasarkan karakteristik diare}

Pola kuman berdasarkan karakteristik diare terlihat dalam tabel 3.

Tabel 3. Profil bakteri berdasarkan sifat diare.

\begin{tabular}{|c|c|c|c|c|c|}
\hline Lendir (+) & Lendir (-) & Darah (+) & Darah (-) & Cair (+) & Cair (-) \\
\hline E coli HS & E coli HS & $T D(3)$ & E coli HS (2) & E coli HS (2) & $\begin{array}{l}\text { E coli 277-84 } \\
\text { (2) }\end{array}$ \\
\hline$T D(3)$ & $T D(5)$ & E coli 277-84 & $T D(7)$ & E coli ECOR38 & E coli 277-84 \\
\hline $\begin{array}{l}\text { E coli 1827-9 } \\
\text { (2) }\end{array}$ & E coli $277-84$ & E coli SC373/2 & E coli $1827-9(2)$ & E coli SC373/2 & \\
\hline $\begin{array}{l}\text { E coli } 277-84 \\
\text { (2) }\end{array}$ & E coli SC373/2 & & E coli 5306-56 & $T D(5)$ & E coli SC373/2 \\
\hline $\begin{array}{l}\text { E coli } \\
\text { ATCC8739 }\end{array}$ & E coli 5306-56 & & E coli 89.0609 & E coli $1827-9$ & Salmonella ${ }^{2}$ \\
\hline E coli ECOR38 & E coli 89.0609 & & E coli A9619-2 & $\begin{array}{l}\text { E coli 5306- } \\
56(2)\end{array}$ & \\
\hline E coli FDA269 & E coli A9619-2 & & $\begin{array}{l}\text { E coli } \\
\text { ATCC } 8739\end{array}$ & E coli 89.0609 & \\
\hline $\begin{array}{l}\text { E coli SC373/2 } \\
\text { (2) }\end{array}$ & $\begin{array}{l}\text { E coli } \\
\text { ATCC } 8739\end{array}$ & & $\begin{array}{l}\text { E coli } \\
\text { ATCC } 8739\end{array}$ & E coli A9619-2 & \\
\hline Salmonella 2 & E coli B170 & & E coli B170 & $\begin{array}{l}\text { E coli } \\
\text { ATCC8739 (2) }\end{array}$ & \\
\hline \multirow{19}{*}{$\begin{array}{l}\text { Enterobacter } \\
\text { cloacae }\end{array}$} & E coli B2F1 & & E coli B2F1 & E coli B170 & \\
\hline & E coli Dec11a & & E coli Dec11a & E coli B2F1 & \\
\hline & E coli Dec12a & & E coli Dec12a & E coli Dec11a & \\
\hline & E coli DEC1a & & E coli DEC1a & E coli Dec12a & \\
\hline & E coli E2348/69 & & E coli E2348/69 & E coli DEC1a & \\
\hline & E coli ECOR38 & & $\begin{array}{l}\text { E coli } \\
\text { ECOR38(3) }\end{array}$ & E coli $D H 10 B$ & \\
\hline & E coli ECOR38 & & E coli E2348/69 & & \\
\hline & E coli ECOR38 & & E coli ECOR28 & & \\
\hline & E coli ECOR48 & & E coli ECOR48 & $\begin{array}{l}\text { E coli } \\
\text { ECOR38(2) }\end{array}$ & \\
\hline & E coli ECOR6 & & E coli ECOR6 & E coli ECOR48 & \\
\hline & E coli ED1a & & E coli ED1a & E coli ECOR6 & \\
\hline & E coli IAI1(2) & & E coli FDA269 & E coli ED1a & \\
\hline & $\begin{array}{l}\text { E coli K-12 } \\
\text { substr MG1655 }\end{array}$ & & E coli IAI1(2) & E coli FDA269 & \\
\hline & E coli LT-91 & & $\begin{array}{l}\text { E coli K-12 } \\
\text { substr MG1655 }\end{array}$ & E coli IAI1(2) & \\
\hline & $\begin{array}{l}\text { E coli } O 157 \\
\text { not } H 7(2)\end{array}$ & & E coli LT-91 & $\begin{array}{l}\text { E coli K-12 } \\
\text { substr MG1655 }\end{array}$ & \\
\hline & E coli1758-70 & & $\begin{array}{l}\text { E coli O } 157 \\
\text { not } H 7(2)\end{array}$ & E coli $L T-91$ & \\
\hline & Salmonella ${ }^{2}$ & & E coli1758-70 & $\begin{array}{l}\text { E coli O } 157 \\
\text { not } H 7(2)\end{array}$ & \\
\hline & Koxytoca & & Salmonella ${ }^{2}(2)$ & E coli1758-70 & \\
\hline & & & $\begin{array}{l}\text { Enterobacter } \\
\text { cloacae } \\
\text { Koxytoca }\end{array}$ & $\begin{array}{l}\text { Enterobacter } \\
\text { cloacae } \\
\text { Koxytoca }\end{array}$ & \\
\hline
\end{tabular}

\section{Catatan}

TD : tidak ditemukan bakteri

2 : Enterica subsp Enterica serovar Havana PRLSW9 


\section{Korelasi antara pemberian antibiotika empiris dan deteksi bakteri dengan PCR/ESI-MS}

Pada diagram 5 mengenai kesesuaian antara pemberian antibiotika empirik oleh klinikus dan penemuan bakteri, ternyata masih terdapat perbedaan sebesar 83,3 $\%$ antara pasien tanpa antibiotik empirik namun ditemukan bakteri, dan perbedaan $58,3 \%$ antara pasien dengan antibiotik namun ditemukan bakteri.

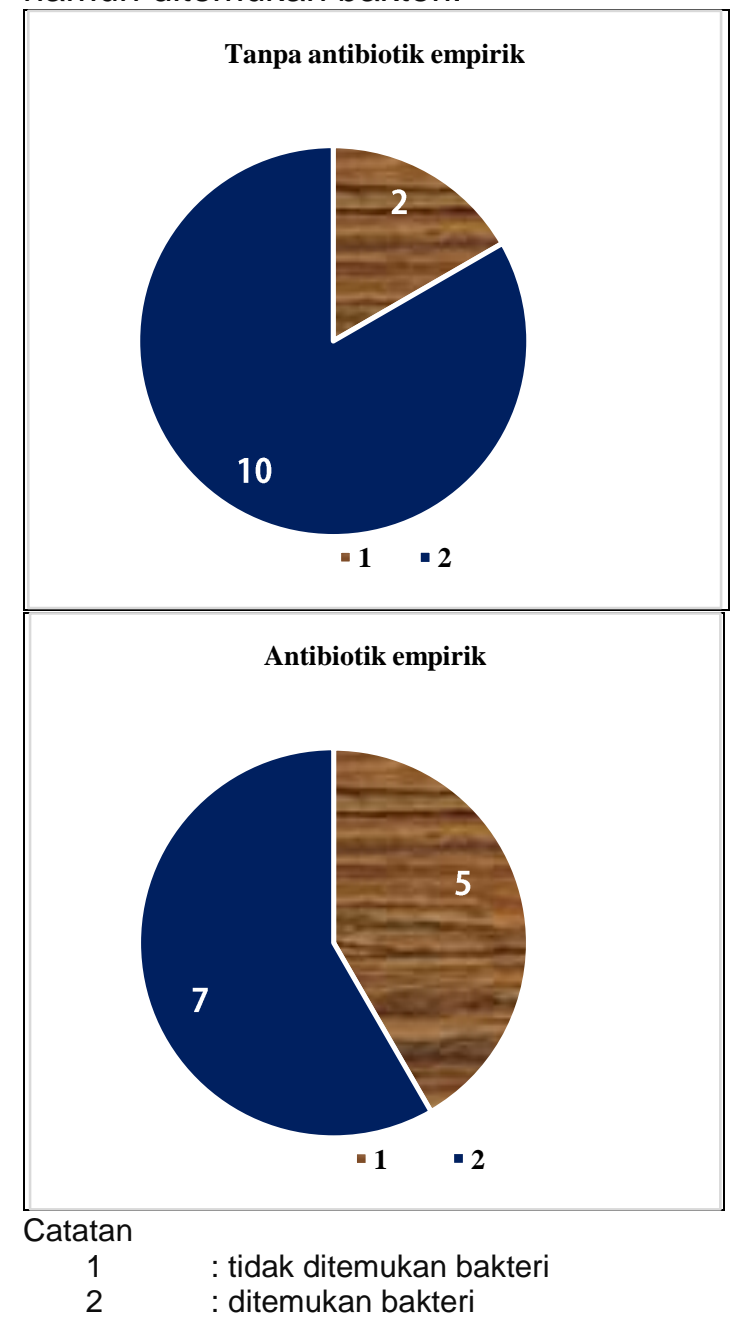

Diagram 5. Kesesuain Pemberian Antibiotik Empirik Dengan Penemuan Bakteri

\section{PEMBAHASAN}

Metoda konvensional untuk deteksi dan identifikasi bakteri patogen memakai biakan kuman yang diikuti identifikasi morfologi dan profil biokimia. Pemeriksaan dengan cara kultur memerlukan waktu antara 24 - 72 jam dan selalu ada kemungkinan gagal apabila kuman sulit atau tidak dapat dikultur. ${ }^{6}$

Penggunaan reaksi rantai polimerase akan mengamplifikasi DNA sasaran hingga satu juta kali dalam waktu kurang dari satu jam, dengan kepekaan hingga satu bakteri patogen saja. Hal ini mengakibatkan PCR memiliki kelebihan dibanding kultur dan metoda konvensional lainnya dalam hal spesifisitas, sensitivitas, kecepatan, akurasi dan kemampuan mendeteksi asam nukleat dalam jumlah sangat sedikit di dalam spesimen. Saat ini mulai dikembangkan teknologi PCR/ESIMS menggunakan primer cakupan luas yang diarahkan pada conserved regions dari genom bakteri yang digabungkan dengan Electrospray Ionization Time-OfFlight (ESI-TOF) dan spektrometri massa, untuk mendeteksi dan mengidentifikasi berbagai patogen tanpa sekuensing asam nukleat. Kepekaan dan resolusi tinggi memungkinkan spektrometri massa membedakan berbagai spesies mikroba berdasarkan variasi subselular. Metodanya mencakup analisis DNA berdasarkan perbedaan massa diantara rantai rantai DNA dengan komposisi basa berbeda. Awalnya, suatu daerah DNA yang berbeda antar spesies maupun subspecies, diamplifikasi dan diidentifikasi massa amplikon. Massa dari tiap basa DNA sudah diketahui, sehingga dapat dicari jumlah basa amplikon. Komposisi maupun jumlah basa, selanjutnya dibandingkan dengan bank data untuk identifikasi kuman. Bank data disusun dari kuman yang telah diketahui sebelumnya dan seluruh genomnya telah diketahui, sehingga memungkinkan identifikasi secara lebih cepat dan mudah dibandingkan sekuensing DNA. Kelebihannya dibanding sekuensing, karena PCR-MS dapat menganalisa spesimen yang mengandung campuran bakteri, pemrosesan lebih sederhana, lebih cepat dan dapat mengekstraksi DNA tanpa harus memurnikan isolasi koloni terlebih dahulu. ${ }^{8,9}$

Proses ekstraksi DNA pada penelitian ini dilakukan secara otomatis, diawali dengan pemecahan dinding sel dengan alat Plex-id bead beater, dilanjutkan dengan ekstraksi asam nukleotida (Plex-id sample preparation), pemindahan hasil 
ekstraksi (Plex-id fluid handler), amplifikasi dengan Plex-id thermocycler, dan terakhir deteksi mikroorganisme memakai Plex-id analyzer. Pada setiap pemeriksaan disertakan kontrol internal positif dan negatif untuk menyingkirkan kemungkinan adanya inhibitor atau kontaminan. Proses ekstraksi dapat juga dilakukan secara manual, dan hasilnya dianalisa dengan Plex-id analyzer.

Berdasarkan perhitungan jumlah sampel, direncanakan jumlah subyek sebesar empat puluh tiga anak dengan diare akut, namun hanya 24 spesimen subyek penelitian yang dapat dianalisa dengan PCR/ESI-MS. Dua puluh empat subyek penelitian tersebut, terdiri dari 10 $(41.7 \%)$ anak laki laki dan 14 (58.3\%) anak perempuan.

Manifestasi klinis yang dijumpai pada subyek penelitian, meliputi muntah sebanyak 17 kasus, diikuti sakit perut 11 kasus dan demam sebanyak 9 kasus. Sebagian besar subyek (75\%) menderita diare dengan frekuensi antara $\leq 5$ kali per hari, disusul 20,8\% antara 6-10 per hari dan hanya satu subyek (4,16\%) dengan frekuensi diare lebih dari sepuluh kali per hari. Karakteristik diare pada subyek penelitian terdiri dari diare berbentuk cair sebanyak 20 kasus, lendir 20 kasus dan darah hanya 3 kasus.

Pada penelitian ini, ditemukan bakteri penyebab diare pada 17 spesimen, dan tidak ditemukan kuman pada 7 kasus. Jumlah bakteri yang ditemukan pada satu spesimen, bervariasi antara satu bakteri sebesar $33.3 \%$, dua bakteri dan empat bakteri yang masing masing sebesar $12.5 \%$, serta tiga bakteri dan enam bakteri yang berjumlah $4.2 \%$. Mikroba yang ditemukan hampir semuanya didominasi $E$. Coli, kecuali tiga kasus yang berbeda yaitu Enterobacter cloacae, Enterica serovar Havana, dan Klebsiella oxytoca. Tidak ditemukan bakteri pada 7 spesimen dapat berarti tidak ada bakteri, namun tidak tertutup kemungkinan adanya bakteri yang tidak terdeteksi. Hal ini dimungkinkan karena cakupan panel food borne pathogen terbatas pada bakteri enteric pathogen, $E$. Coli, Salmonella, Shigella dan Listeria, berdasarkan primernya terhadap mutS (DNA mismatch repair protein), mdh (malate dehydrogenase), prfA (peptide chain release factor) dan iap ( invasion associated protein). Selain itu kemungkinan adanya virus sebagai penyebab diare tidak dapat disingkirkan meskipun hanya anak usia di atas lima tahun yang dimasukkan sebagai subyek dalam penelitian ini. Bakteri yang dijumpai berbeda dengan bakteri hasil kultur, karena memakai nomenklatur molekular. Diperlukan suatu penelitian lanjutan untuk mengetahui kesesuaian teknologi ini dengan kultur konvensional, sehingga bermanfaat untuk penatalaksanaan pasien.Teknologi ini akan sangat bermanfaat pada surveilans dan kejadian luar biasa, deskripsi bakteri lebih rinci dapat hubungan kausal antara bakteri pada makanan penyebab diare dan bakteri yang dideteksi pada pasien.

Pada penelitian ini, hampir semua bakteri yang ditemukan merupakan Escherichia coli. Meskipun tanpa uji kepekaan, sebaiknya pemberian terapi empirik pada anak dengan diare akut diarahkan pada jenis antibiotik yang diperkirakan mampu menghambat pertumbuhan atau mematikan E. coli seperti golongan sefalosporin, amoksisilin, atau trimetoprim - sulfametoksazol.

Apabila dilihat jenis bakteri yang ditemukan berdasarkan pengelompokkan keluhan subyek, ternyata bakteri $E$. coli FDA29hanya dijumpai pada subyek dengan keluhan demam, sakit perut atau muntah, dan tidak ditemukan pada kasus tanpa adanya salah satu karakteristik klinis tersebut. Sementara E. coli IAI1 dan E. coli ECOR28 ditemukan pada kasus demam dan muntah, namun juga dideteksi pada kasus tanpa sakit perut, dan tampaknya kurang berkaitan dengan keparahan penyakit. Berdasarkan pengelompokkan menurut sifat diare, ditemukan bakteri $E$. coli 277-84 dan $E$ coli SC373/2 pada kasus diare disertai lendir dan diare berdarah, namun tidak dijumpai pada klasifikasi diare cair. Selain itu, spesimen yang tidak terdeteksi bakteri, lebih banyak pada kasus diare tanpa lendir dan diare tanpa darah, namun justru lebih banyak pada kasus diare cair dibanding diare tidak cair. Hal ini diduga karena karakteristik cair dan tidak cair tidak merepresentasikan derajat 
diare, dan tidak ada penjabaran kriteria cair atau tidak cair dalam kuesioner, sehingga responden rancu dalam membedakannya. Penelitian lanjutan perlu dilakukan untuk mengelaborasi patogenitas bakteri tersebut di atas.

Apabila dilihat kesesuaian antara rencana pemberian antibiotik empirik dan penemuan bakteri, ternyata hanya 9 kasus atau $37.5 \%$ yang sesuai. Persentase terbesar justru pada ketidak sesuaian antara penemuan bakteri dan pemberian antibiotik empirik yang mencapai $62.5 \%$. Berdasarkan hal ini, dapat disimpulkan bahwa penemuan mikroba penyebab diare masih sangat menentukan penanganan pasien yang tepat.

Pada penelitian ini, seluruh proses pemeriksaan dari ekstraksi hingga pembacaan, apabila digabungkan hanya memerlukan waktu kurang dari 24 jam, dan jauh lebih cepat dibanding kultur. Selain itu, metoda PCR-ESI/MS mampu mengidentifikasi berbagai mikroorganisme dalam spesimen tunggal. Awalnya teknologi ini dianggap mahal karena memerlukan biaya investasi pengadaan alat dan ruangan molekular, disamping biaya pemeriksaan spesimen antara lima puluh hingga seratus dolar per tes. Namun, penemuan bakteri lebih dari satu per spesimen bahkan ada yang 8 kuman, dengan pemeriksaan tunggal, membalikkan asumsi tersebut. Biaya yang dikeluarkan tidak lebih mahal dibanding melakukan pemeriksaan dengan metoda PCR konvensional maupun kultur berkali kali agar dapat mendeteksi bakteri yang sama dengan PCR-ESI/MS, selain waktu periksa yang jauh lebih cepat. Sama halnya dengan pemeriksaan laboratorium lainnya, biaya akan meningkat apabila memerlukan lebih dari satu jenis panel atau jumlah spesimen terbatas. Kelebihan lainnya, teknologi ini mampu mendeteksi berbagai bakteri dalam waktu 24 jam, sesuatu yang sangat diperlukan dalam penanganan kejadian luar biasa. ${ }^{9}$

Keterbatasannya, teknologi PCRESI/MS bersifat semikuantitatif, memerlukan intensitas organisme tertentu agar dapat diidentifikasi, serta dipengaruhi jumlah primer dan yang dipakai dan komposisi database. Selain itu, karena kepekaannya,metoda deteksi spektrometri massa dapat terkontaminasi apabila tidak menggunakan reagen sangat murni dan bebas DNA.

\section{KESIMPULAN}

Berdasarkan hasil yang diperoleh dalam penelitian ini, yaitu 24 subyek penelitian yang memenuhi kriteria dan pembahasan yang telah dilakukan dapat ditarik kesimpulan sebagai berikut:

1. Manifestasi klinis yang dijumpai pada subyek penelitian, meliputi muntah, sakit perut, dan demam. Sementara diare berbentuk cair merupakan karakteristik diare terbanyak, disusul diare lendir dan darah. Mayoritas frekuensi diare pada subyek penelitian, berkisar antara 1- 5 kali per hari.

2. Pada penelitian ini ditemukan 29 jenis bakteri dan hampir semuanya didominasi E. Coli, kecuali tiga kasus yang berbeda yaitu $E$. cloacae, Salmonella Enterica subsp Enterica serovar Havana, dan Klebsiella oxytoca.Jumlah bakteri per subyek penelitian umumnya lebih dari satu. Bakteri E. coli FDA29 merupakan satu satunya bakteri yang ditemukan pada kasus demam, sakit perut dan muntah namun tidak ditemukan pada kasus tanpa manifestasi klinis tersebut. Jenis bakteri yang didapat dengan PCR/ESIMS berbeda dengan kultur, dan lebih bermanfaat untuk surveilans maupun kejadian luar biasa.

3. Persentase kesesuaian antara terapi antibiotik secara empirik dan ada tidaknya kuman dengan PCR/ESI-MS ternyata lebih sedikit dibanding yang tidak sesuai. Hal ini menunjukkan masih pentingnya deteksi mikroorganisme dalam penatalaksanaan diare.

4. Teknologi ini terbukti jauh lebih cepat dibanding kultur, dapat mendeteksi lebih dari satu bakteri per spesimen dengna deskripsi lebih spesifik, dan bermanfaat untuk surveilan. 


\section{SARAN}

Perlu dilakukan penelitian lanjutan untuk mengetahui korelasi antara bakteri yang dideteksi dengan teknologi PCR/ESI-MS dengan biakan mikrobiologi, agar dapat diaplikasikan secara klinis.

Memberikan masukan bagi penentu kebijakan untuk dapat melakukan penerapan dan pengkajian lebih lanjut teknologi PCR/ESI-MS pada surveilan dan kejadian luar biasa akibat penyakit makanan.

\section{DAFTAR PUSTAKA}

1. WHO. Diarrhoeal disease, WHO fact sheet 330(internet). 2013 (cited 2015 Jan) Available from: http: //www. who.int/mediacentre/factsheets/fs330/e $\mathrm{n} /$ \#content

2. Betts $R$, Blackburn $C$. Detecting Pathogens in Food. In Blackburn C, McClure P. Foodborne pathogens Hazards, risk analysis and control. 1 st ed. Cambridge : Woodhead ; 2002.p.13-45.

3. Detection, Identifi cation, and Analysis of Foodborne Pathogens. In Campos GL, Joaquin V, Suarez M, Urda MA, Alonso VL. Microarray Detection and Characterization of Bacterial Foodborne Pathogens. Guilermo : SpringerBriefs in Food, Health, and Nutrition; 2012.p.13-32.

4. Wolk DM, Kaleta EJ, Wysocki VH. Review PCR-Electrospray Ionization Mass Spectrometry. The Potential to Change Infectious Disease Diagnostics in Clinical and Public Health Laboratories . JMD 2012 ; 7(4) : 295304.

5. Abbott Food-Borne Bacteria E coli, Salmonella, Shigella, and Listeria Assay Kit. 2010 Abbott Molecular, Inc

6. Velusamy V, Arshak K, Korotstynska O, Oliwa K, Adley C. An overview of foodborne pathogen detection: In the perspective of biosensors. Biotech Advances 2010; 28: 232-54.

7. Pierce SE, Bell RL, Hellberg RS, Cheng CM, Chen KS, Williams-Hill DM, et all. Detection and Identification of Salmonella enterica, Escherichia coli, and Shigella spp. via PCR-Electrospray Ionization Mass Spectrometry: Isolate Testing and Analysis of Food Samples. Appl. Environ. Microbiol. 2012; 78(23):8403-8411.

8. Shen JL, Wang F, Housley R, Carolan $\mathrm{H}$, Yasuda I, Burrows E, et all. Rapid Identification and Differentiation of NonO157 Shiga Toxin-Producing Escherichia coli Using Polymerase Chain Reaction Coupled to Electrospray Ionization Mass Spectrometry. Foodborne Pathog Dis. 2013; 10(8) : 1-7.

9. Wolk DM, Kaleta EJ, Wysocki VH. Review PCR-Electrospray Ionization Mass Spectrometry The Potential to Change Infectious Disease Diagnostics in Clinical and Public Health Laboratories. JMD. 2012; 14(4): 295304.

10. Cunha BA, Schoch PE, Bottone EJ, Rex JH, Stollo S. Antibiotic Susceptibillity Profiles and Initial Therapy of Isolates Pending Suceptibility Results. In : Cunha BA. Antibiotic Essentials. $10^{\text {th }}$ ed. London : Jones \& Barlett Learning. 2011.p.183247. 